\title{
TEKNIK PEMBESARAN IKAN NILA (Oreochromis niloticus) DI INSTALASI BUDIDAYA AIR TAWAR PANDAAN, JAWA TIMUR
}

\section{Enlargement Technique of Tilapia (Oreochromis niloticus) in Freshwater Aquaculture Installation Pandaan, East Java}

\author{
Meidiana Salsabila ${ }^{1 *}$ dan Hari Suprapto ${ }^{2}$. \\ ${ }^{1}$ Program Studi Budidaya Perairan, Fakultas Perikanan dan Kelautan, Universitas Airlangga, Surabaya \\ ${ }^{2}$ Departemen Manajemen Kesehatan Ikan dan Budidaya Perairan, Fakultas Perikanan dan Kelautan, Universitas \\ Airlangga, Surabaya \\ *meidiana.salsabila-2015@fpk.unair.ac.id
}

\begin{abstract}
Abstrak
Ikan nila merupakan ikan yang banyak dikonsumsi oleh masyarakat di Indonesia. Permintaan pasar akan ikan nila mengalami kenaikan setiap tahunnya, sehingga produksi ikan nila perlu ditingkatkan lagi, terutama pada proses pembesaran ikan nila. Tujuan dari praktek kerja lapang ini adalah mengetahui secara langsung tentang teknik pembesaran secara semi-intesif pada ikan nila (Oreochromis niloticus) di Instalasi Budidaya Air Tawar (IBAT) Pandaan, Jawa Timur dan mengetahui permasalahan yang terjadi dalam teknik pembesaran secara semi-intensif pada ikan nila (Oreochromis niloticus) di Instalasi Budidaya Air Tawar (IBAT) Pandaan, Jawa Timur. Kegiatan pembesaran ikan nila meliputi persiapan kolam, penebaran benih, pemberian pakan, pengelolaan kualitas air, pengendalian hama dan penyakit, serta pemanenan. Persiapan kolam meliputi pengeringan tanah, pembalikan tanah, pengapuran, dan pengisian air. Pengeringan dilakukan selama 1-2 minggu atau tergantung cuaca hingga tanah tampak retak. Pembalikan tanah dilakukan setelah tanah kering dan dicangkul dengan kedalaman 5-10 cm. Pengapuran dilakukan dengan menggunakan kapur dolomit dengan dosis 70 gram per $\mathrm{m}^{2}$ dan dibiarkan hingga 2 hari. Kemudian kolam diisi dengan air hingga mencapai ketinggian 50$60 \mathrm{~cm}$.Benih yang ditebar di kolam pembesaran memiliki ukuran 3-5 cm dengan padat tebar 30-50 ekor per m². Dosis pakan yang diberikan sebanyak 3\% dari total berat ikan nila. Selama kegiatan Praktek Kerja Lapang tidak ditemukan ikan yang terkena penyakit, namun ditemukan beberapa hama di kolam yang berupa siput air. Kualitas air yang diukur terdiri dari dissolved oxygen atau oksigen terlarut, suhu, pH, dan kecerahan. Kadar oksigen terlarut berkisar antara 4,00-6,50 mg/L, suhu antara 27-30 ${ }^{\circ} \mathrm{C}, \mathrm{pH}$ 6,0-6,5, dan kecerahan $31 \mathrm{~cm}$. Untuk mengetahui pertumbuhan ikan nila, dilakukan sampling setiap minggunya dengan mengukur panjang dan berat ikan.
\end{abstract}

Kata kunci: Oreochromis niloticus dan Pembesaran

\begin{abstract}
Tilapia is one of popular fish that consume daily in Indonesia. The market demands of tilapia is increasing in every year which is we need to improve the tilapia enlargement. The purpose of this field practice is to get to know the technique of the tilapia (Oreochromis niloticus) enlargement in a semi-intensive way and also to know the problems at Freshwater Aquaculture Installation (IBAT) Pandaan, East Java. The activity of the tilapia (Oreochromis niloticus) enlargement include pond preparation, feeding, water quality control, and disease and pest control. The pond preparation including soil draining, soil reversal, soil liming, and irrigation. The soil draining require 1-2 weeks or depends on weather until the soil looks cracky. The soil reversal were done after the soil is dry and hoes with $5-10 \mathrm{~cm}$ depth. The soil liming was done by using dolomite with $70 \mathrm{~g} / \mathrm{m}^{2}$ dose and rested until 2 days. After all the process done, the pond filled with water until 50-60 cm high. The juveniles that are spread in the enlargement pond have $3-5 \mathrm{~cm}$ size with $30-50$ fishes dense stocking per $\mathrm{m}^{2}$. The tilapia feeded with pellets in every morning and evening. The feeding dose is $3 \%$ of their mass body. During the field practice, there was not fish that infected with disease but found some pest in the pond like water snail. The water quality that checked consist of dissolved oxygent, temperature, $\mathrm{pH}$, and brightness. The dissolved oxygent

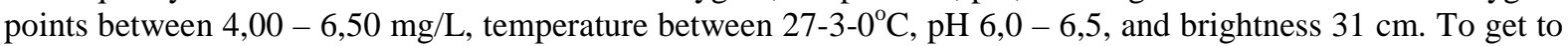
know the tilapia growth, it needs sampling every week by measuring the size and weight of fish.
\end{abstract}

Keywords: Oreochromis niloticus and Enlargement 


\section{PENDAHULUAN}

Indonesia merupakan negara maritim dengan luas perairan sekitar 5,8 juta $\mathrm{km}^{2}$, sehingga memiliki potensi perikanan baik laut maupun tawar. Indonesia memiliki beragam spesies ikan, salah satu jenis ikan yang digemari untuk dikonsumsi adalah ikan demersal. Ikan demersal merupakan ikan yang secara komersial layak untuk diusahakan atau dengan kata lain menguntungkan. Salah satu jenis ikan demersal yang ada di Indonesia di antaranya adalah ikan nila. Ikan nila sering dijumpai di pasaran dalam bentuk olahan maupun bentuk ikan segar. Data statistik Kementerian Kelautan dan Perikanan Indonesia menyatakan bahwa pada tahun 2015 produksi ikan nila di Indonesia mencapai 592.365 ton dengan rata-rata produksi sebanyak 197.455 ton serta persentase pertumbuhan sebesar 22,75\%. Berdasarkan data dari Dinas Perikanan dan Kelautan Jawa Timur bahwa produksi ikan nila di Jawa Timur mengalami peningkatan pada tahun 2009 mencapai 8.521 ton. Jumlah benih ikan yang disebar di kolam yang berada di Pasuruan pada tahun 2014 berdasarkan hasil statistik perikanan budidaya di Jawa Timur yang dilakukan oleh Dinas Kelautan dan Perikanan Jawa Timur yaitu sebanyak 75.800 ekor.

Untuk mencapai ikan yang maksimal diperlukan pemeliharaan yang intensif seperti penambahan pakan tambahan. Adria (2012) mengatakan bahwa pakan buatan dibagi menjadi 3 berdasarkan kebutuhannya yaitu pakan tambahan, pakan suplemen, dan pakan utama. Fungsi pakan tersebut digunakan untuk kelangsungan hidup dan peningkatan produksi ikan. Persyaratan kualitas air untuk pembesaran ikan nila antara lain pH air antara 6,5-8,6, suhu air berkisar $25-30^{\circ} \mathrm{C}$, oksigen terlarut (DO) $>$ $5 \mathrm{mg} / \mathrm{l}$ (ppm), kandungan amoniak (NH3) $<0,02 \mathrm{ppm}$, debit air untuk kolam air tenang 8-15 liter/detik/ha, kualitas air harus bersih tidak terlalu keruh dan tidak tercemar bahan-bahan kimia beracun.
Pola budidaya nila perlu dikembangkan lebih intensif karena laju konversi lahan tambak terjadi sepanjang waktu. Berkembangnya industri dan kota baru dikhawatirkan akan berdampak pada penurunan produksi dan produktifitas nila. Di sisi lain kebutuhan nila terus meningkat seiring dengan peningkatan jumlah penduduk dan makin tingginya kesadaran masyarakat untuk mengkonsumsi sumber protein yang menyehatkan dan berlemak rendah. Untuk melindungi kawasan tambak diperlukan upaya yang sinergis antara pengambil kebijakan, pembudidaya dan pengusaha agar budidaya nila lebih luas.

Atas dasar pemikiran tersebut dan pentingnya pembesaran pada ikan nila untuk dikonsumsi pada masyarakat maka perlu dilakukan Praktek Kerja Lapang (PKL) untuk mempelajari pembesaran ikan nila (Oreochromis niloticus) di Instalasi Budidaya Air Tawar Pandaan, Jawa Timur.

\section{METODOLOGI}

\section{Waktu dan Tempat}

Kegiatan Praktek Kerja Lapang ini dilaksanakan di Instalasi Budidaya Air Tawar (IBAT) Pandaan, Pasuruan, Jawa Timur. Kegiatan ini dilaksanakan pada tanggal 18 Desember 2017 hingga 18 Januari 2018

\section{Metode Penelitian}

Metode pengambilan data dilakukan dengan proses observasi atau pengamatan secara langsung. Pengambilan data juga dilakukan melalui wawancara dengan pihak terkait. Data yang terkumpul antara lain profil unit usaha, proses persiapan kolam pembesaran ikan, penebaran benih ikan, pemberian pakan ikan, pertumbuhan ikan, pengelolaan kualitas air, pengendalian hama, pemanenan, dan pemasaran ikan.

\section{Prosedur Kerja \\ Persiapan Kolam Pembesaran}


Persiapan kolam pembesaran terdiri dari pengeringan tanah, pembalikan tanah, pengapuran tanah, dan pengisian air yang dilaksanakan selama kurang lebih 2 minggu. Peralatan dan bahan yang digunakan antara lain kolam tanah, cangkul, pompa air, dan 100 kg kapur dolomit.

\section{Penebaran Benih}

Benih ikan nila yang akan ditebar di kolam pembesaran diaklimatisasi terlebih dahulu untuk menyesuaikan suhu di lingkungan baru. Peralatan dan bahan yang digunakan antara lain plastik, air, dan oksigen.

\section{Pemberian Pakan Ikan}

Ikan diberikan pakan berupa pellet HI PRO-VITE 781-3 yang diproduksi oleh PT. CP Prima. Jumlah pakan yang diberikan sebanyak 3\% berat ikan dengan frekuensi pemberian pakan 2 kali sehari.

\section{Pertumbuhan Ikan}

Pertumbuhan ikan diukur setiap seminggu sekali dengan parameter panjang dan berat. Peralatan dan bahan yang digunakan antara lain 50 ekor ikan nila, penggaris, dan neraca digital.

\section{Pengelolaan Kualitas Air}

Kualitas air diukur setiap harinya dengan parameter oksigen terlarut, suhu, kecerahan, dan $\mathrm{pH}$. Peralatan yang digunakan antara lain DO meter, $\mathrm{pH}$ meter, dan secchi disk.

\section{Pemanenan Ikan}

Ikan dipanen setelah 3 bulan masa pemeliharaan atau setelah mencapai ukuran konsumsi. Ikan dipanen secara diseser dengan menggunakan jaring dan pellet untuk mengumpan ikan.

\section{HASIL DAN PEMBAHASAN Pengeringan Tanah Dasar Kolam}

Setelah digunakan untuk satu siklus pembesaran ikan nila, dasar kolam menjadi kubangan lumpur organik akibat terjadi pengendapan berbagai bangkai organisme perairan seperti plankton serta adanya sisa pakan yang mengendap. Proses pengeringan dilakukan selama 1-2 minggu atau tergantung cuaca hingga tanah tampak retak (Prihatini, 2014). Pengeringan dilakukan dengan bantuan matahari bertujuan untuk mengoksidasi bahan organik yang yang terkandung di dalam tanah menjadi mineral atau hara.

\section{Pembalikan Tanah}

Pembalikan tanah atau pengangkatan lumpur dilakukan setelah tanah dasar kolam kering. Pembalikan tanah dilakukan dengan cara mencangkul tanah dengan kedalaman 5-10 cm (Prihatini, 2014). Pembalikan tanah berfungsi untuk mengurangi kandungan bahan organik di dasar kolam serta dapat meninggikan pematang dan menutup kebocoran pematang.

\section{Pengapuran Tanah}

Pengapuran tanah dilakukan setelah tanah dasar mengering dan dibalik. Jenis kapur yang digunakan adalah kapur dolomit dengan dosis 70 gram per $\mathrm{m}^{2}$, berbeda dengan Prihatini (2014) yang menggunakan kapur kalsit dengan dosis 100 gram per $\mathrm{m}^{2}$ Pengapuran dilakukan dengan tujuan untuk meningkatkan $\mathrm{pH}$ serta membunuh patogen dan hama. Pada $\mathrm{pH}$ yang rendah, kondisi perairan umumnya rendah dan efek pemupukan tidak signifikan.

\section{Pengisian Air}

Kolam diisi dengan air melalui saluran inlet 2 hari setelah pengapuran. Pengairan dilakukan hingga air mencapai ketinggian 50-60 cm. Pengairan pertama dilakukan dengan mengisi air hingga mencapai ketinggian $15-20 \mathrm{~cm}$ dan dibiarkan selama 3-5 hari. Pada ketinggian ini sinar matahari masih dapat mencapai dasar kolam sebagai syarat tumbuhnya fitoplankton. Sebelum menebar benih, kolam diisi air kembali sebagai proses pengisian air lanjutan hingga mencapai 
ketinggian yang ditentukan. Setelah dilakukan pengisian air lanjutan diharapkan kondisi lingkungan menjadi stabil dan kapasitas oksigen meningkat.

\section{Penebaran Benih}

Benih yang akan ditebar sebaiknya diaklimatisasi terlebih dahulu guna menentukan keberhasilan pada kegiatan pembesaran ikan nila. Aklimatisasi bertujuan untuk menyesuaikan kondisi lingkungan yang baru dengan lingkungan sebelumnya, dengan kata lain suhu air dalam kantong plastik disetarakan dengan suhu air di dalam kolam pembesaran.

Sebelum dilakukan penebaran benih, sebaiknya dilakukan seleksi benih guna menjaga keseragaman ukuran benih. Ukuran benih ikan nila yang ditebar di kolam pembesaran berkisar 3-5 cm dengan usia 2 minggu. Menurut Yuliati dkk. (2003), pada umumnya ikan nila yang disebar di kolam pembesaran memiliki berat 10-20 gram per ekor.

\section{Pemberian Pakan}

Ikan nila diberi pakan dengan dosis sebanyak 3\% dari berat tubuh ikan dengan frekuensi pemberian 2 kali, yaitu pada pagi dan sore hari. Pemberian pakan sebanyak 2 kali sehari dengan dosis 3\% dari bobot ikan mampu meningkatkan berat tubuh ikan nila secara optimal. Sesuai dengan pernyataan Popma dan Lovshin (1994), berat tubuh ikan meningkat secara optimal jika diberi pakan sebanyak 2,5-4\% berat tubuh ikan.

Feed convertion ratio adalah rasio jumlah pakan yang dibutuhkan untuk menghasilkan daging ikan. Semakin kecil nilai FCR, maka menunjukkan indikasi baik dari pakan berkualitas tinggi (USAID, 2011). Nilai FCR yang diperoleh yaitu sebesar 0,51, yang berarti 0,51 kg pakan dapat menghasilkan $1 \mathrm{~kg}$ daging ikan.

\section{Pertumbuhan}

Pertumbuhan merupakan pertambahan ukuran, panjang, maupun berat dalam satu waktu (Riani, 2012).
Untuk mengetahui pertumbuhan ikan, perlu dilakukan sampling ikan setiap seminggu sekali. Sampling juga berguna untuk mengetahui jumlah pakan yang akan diberikan pada ikan sesuai dengan pertumbuhannya.

Laju pertumbuhan yang diperoleh selama Praktek Kerja Lapang yaitu sebesar 8,526 dengan laju pertumbuhan sebesar 6,66\%. Laju pertumbuhan yang meningkat dapat disebabkan oleh meningkatnya konsentrasi tiroksin dan triiodotironin dalam plasma darah ikan pada saat diberi pakan kembali setelah dipuasakan.

\section{Oksigen Terlarut}

Rerata kadar oksigen terlarut pada kolam pembesaran ikan nila berkisar antara 4,20-6,34 mg/L. Hal ini sesuai dengan SNI 7550:2009 yang menyebutkan bahwa kadar oksigen terlarut yang optimal untuk pembesaran ikan nila lebih dari 3 $\mathrm{mg} / \mathrm{L}$. Faktor yang mempengaruhi perbedaan oksigen terlarut adalah pengaruh dari aktivitas pada kolam sehingga mudah terjadi difusi oksigen dari udara ke air. Selain itu, oksigen terlarut juga dipengaruhi oleh kelimpahan fitoplankton.

\section{Suhu}

Rerata suhu air di kolam pembesaran ikan nila berkisar antara 27,7$29,3{ }^{\circ} \mathrm{C}$. Hal ini sesuai dengan SNI 7550:2009 di mana ikan akan tumbuh dengan optimal pada suhu perairan sekitar $25-32^{\circ} \mathrm{C}$. Menurut Mukti dkk. (2015), suhu air memiliki pengaruh yang besar terhadap proses pertukaran zat atau metabolisme dari ikan.

pH

Rerata $\mathrm{pH}$ pada kolam pembesaran ikan nila berkisar antara 6,4-6,6. Hal ini sesuai dengan SNI 7550:2009 yang menyebutkan bahwa $\mathrm{pH}$ yang optimal untuk kegiatan pembesaran ikan nila adalah 6,5-8,5. Menurut Zonneveld (1991) dalam Mukti dkk. (2015), pH dapat 
digunakan sebagai indikator daya produksi perairan.

\section{Kecerahan}

Rata-rata kecerahan pada kolam pembesaran ikan nila yaitu antara 31-32 cm. Sesuai dengan SNI 7550:2009, bahwa kecerahan optimal untuk pembesaran ikan nila yaitu sekitar 30-40 cm. Dengan kecerahan mencapai 30-40 cm, sinar matahari masih dapat menembus perairan sehingga fitoplankton dapat berfotosintesis (Mukti dkk., 2015).

\section{Pengendalian Hama}

Selama kegiatan Praktek Kerja Lapangan dilakukan, tidak ditemukan adanya penyakit. Tidak adanya penyakit ini dikarenakan kualitas air kolam terjaga dengan baik. Namun terdapat hama seperti siput air dan kepiting. Pencegahan hama dapat dilakukan pada tahap persiapan kolam, yaitu dengan pengeringan kolam dengan baik dan dengan pemberian zat-zat racun (Prihatini, 2014).

\section{Pemanenan}

Ikan yang sudah mencapai ukuran konsumsi yang sesuai dengan permintaan pasar dipanen. Kolam yang akan dipanen airnya dikurangi terlebih dahulu secara perlahan dan bertahap. Setelah air surut, ikan diambil dengan cara diseser, yaitu menggunakan jaring yang dipegang oleh minimal 2 orang. Ikan yang sudah terambil dimasukkan ke dalam bak penampung. Tujuan ikan dimasukkan ke dalam bak penampung adalah untuk menjaga ikan tetap segar hingga saat packing.

\section{Pemasaran}

Sasaran pemasaran ikan nila yang dibudidayakan adalah masyarakat sekitar Instalasi Budidaya Air Tawar Pandaan. Pembeli datang langsung ke Instalasi Budidaya Air Tawar Pandaan. Harga jual ikan nila Rp 20.000 untuk ukuran 3 dan Rp 25.000 untuk ukuran 5. Ikan yang dibeli dimasukkan ke dalam kantong plastik yang berisi air dan diberi oksigen dengan perbandingan 1:2. Daerah pemasaran ikan nila dari Instalasi Budidaya Air Tawar Pandaan mencakup wilayah Jawa Timur seperti Sidoarjo, Pasuruan, dan Malang.

\section{KESIMPULAN DAN SARAN Kesimpulan}

Hal yang dapat disimpulkan dari kegiatan pembesaran ikan nila di Instalasi Budidaya Air Tawar meliputi persiapan kolam, penebaran benih, pemberian pakan, pengelolaan kualitas air, pengendalian hama dan penyakit, pemanenan, dan pemasaran. Permasalahan yang ada pada pembesaran ikan nila adalah banyaknya hama sepert siput air pada kolam dan cukup sulit untuk dibasmi. Selain itu, faktor cuaca juga dapat mempengaruhi fluktuasi kualitas air.

\section{Saran}

Sebaiknya Instalasi Budidaya Air Tawar Pandaan lebih meningkatkan jumlah produksi ikan nila karena permintaan konsumen yang semakin meningkat. Selain itu, manajemen kualitas air perlu ditingkatkan lagi untuk menghindari adanya hama dan penyakit di kolam pembesaran ikan nila tersebut.

\section{DAFTAR PUSTAKA}

Adria, P. M. 2012. Pengaruh Stimulan Pakan Ikan (SPI) untuk Pembesaran Nila Merah (Oreochromis sp.) yang Dipelihara di Waring Ikan. Prosiding Simposium dan Pameran Teknologi Aplikasi Isotop dan Radiasi.

Mukti, A. T., M. Arief, dan W. H. Satyantini. 2015. Dasar-dasar Akuakultur. Universitas Airlangga. Surabaya.

Popma, T. J. and L. L Lovshin. 1994. World Prospect For Commercial Production of Tilapia. Research and Development Series No. 41. International Center for Aquaculture and Aquatic 
Environments. Department of Fisheries and Allied Aquacultures Auburn University. Alabama.

Prihatini , E. S. 2014. Manajemen Kualitas Air Pada Pembesaran Ikan Nila Salin (Oreochromis aureus $\mathrm{X}$ niloticus) di Instalasi Budidaya Air Payau Kabupaten Lamongan. Grouper Faperik 2014.

Riani, H. 2012. Efek Pengurangan Pakan Terhadap Pertumbuhan Udang Vaname (Litopenaues vannamei) PL-21 yang Diberi Bioflok. Skripsi. Program Studi Sarjana Perikanan. Universitas Padjadjaran.

SNI 7550. 2009. Produksi Ikan Nila (Oreochromis niloticus Bleeker) Kelas Pembesaran di Kolam Air Tenang. Badan Standardisasi Nasional. Jakarta.

[USAID] United States Agency for International Development. 2011. Feed Conversion Ratio (FCR). USAID-Harvest. Phnom Penh.

Yuliati, P., T. Kadarini, Rusmaedi, dan S. Subandiyah. 2003. Pengaruh Padat Penebaran Terhadap Pertumbuhan dan Sintasan Dederan Ikan Nila Gift (Oreochromis niloticus) di Kolam. Jurnal Iktiologi Indonesia, 3(2), Desember 2003. 